of Leeds for his work in physical chemistry and in the same year was appointed post-doctoral Fellow at the National Research Laboratories, Ottawa, where he remained until 1954, when he was appointed assistant lecturer in chemistry at the University of Manchester. $\mathrm{He}$ was promoted to lecturer in 1956 and reader-designate earlier this year. His research work has been mainly in the field of spectroscopy and polymer science and he has published numerous papers on these and other subjects in learned journals.

\section{Psychology in the University of Reading: \\ Prof. Magdalen D. Vernon}

Prof. Magdalen D. Vernon, who has been professor of psychology in the University of Reading since 1956 (Nature, 178, 777; 1956), having been appointed lecturer in 1946 and later senior lecturer and reader, retires from her chair in 1967.

Dr. M. Treisman

Dr. M. Treisman has been appointed to succeed Prof. Vernon. He studied medicine in the University of the Witwatersrand during 1947-52. He then practised in South Africa until 1954, when he entered the University of Oxford to read psychology and physiology, holding the Theodore Williams scholarship in physiology. $\mathrm{He}$ obtained first-class honours in these subjects in 1956. During 1956-59 he carried out research, and was a Senior Hulme Scholar at Brasenose College, and during 1958-60 he was a Wellcome Associate of the Royal Society of Medicine. He obtained his D.Phil. in 1962. Dr. Treisman was appointed junior lecturer in experimental psychology in the University of Oxford in 1959, and four years later was promoted to his present position of lecturer. Dr. Treisman's research has been mainly in the fields of sensation and perception. He has been interested in the central factors affecting sensory discrimination, and especially in applying statistical decision theory to elucidate how information given in one modality can affect discrimination in another. This has led to work on auditory masking, discrimination during sleep, and other problems. He has also worked on the scaling of subjective magaitudes, the re-interpretation of certain traditional sensory 'laws', and on temporal discrimination.

\section{Geography in the University of Cambridge :}

Prof. H. C. Darby

Prof. H. C. Darby, who has been appointed to the chair of geography in the University of Cambridge, has held the chair of geography at University College, London, since 1949. He was previously John Rankin professor of geography at the University of Liverpool (1945 until 1949). Prof. Darby was appointed to a lectureship at Cambridge in 1931 and elected Ehrman Fellow at King's College the following year. During the Second World War, following a short period in the Army, he was attached to the Intelligence Department of the Admiralty. While at Liverpool, he also held a Leverhulme Research Fellowship. Since his appointment to London, he has been a visiting professor to the universities of Harvard, Chicago and Washington State. Prof. Darby has made the field of historical geography very much his own and has greatly stimulated interest in the subject on both sides of the Atlantic. His earlier work was on the medieval Fenland and the draining of the Fens. As editor and contributor, he is in the process of publishing a reconstruction of the Domesday geography of England. Four volumes of this study have already appeared. His contributions to geography were recognized in 1963 by the simultaneous awards of the Victoria Medal by the Royal Geographical Society and the Daly Medal by the American Geographical Society. Prof. Darby has been president of both the Institute of British Geographers and Section E of the British Association for the Advancement of Science.
He has demonstrated a practical as well as an academic interest in the landscape and resources of Britain, serving as a member of the Royal Commission on Historical Monuments and of the National Parks Commission. $\mathrm{He}$ is also a member of the recently formed Water Resources Board.

\section{Medical Research Council :}

Second Secretary

IN view of the rapid expansion of its work and its increasing involvement in public affairs, the Medical Research Council has, with the agreement of the Secretary of State for Education and Science, decided that the Secretary of the Council shall in future be reinforced by a Second Secretary who shall act as his deputy and alternate in all respects. Because of the Council's increasing concern with the development of biology, it is believed that the Second Secretary to the Council should be recruited from the field of men who have had experience of research, and have distinguished themselves, in the biological sciences. Accordingly, Prof. J. A. B. Gray, professor of physiology in University College, London, has been appointed to this post. Sir Charles Harington has agreed to occupy the post of Second Secretary in an acting capacity until Prof. Gray takes up duty some time in 1966 .

Prof. J. A. B. Gray

Prof. Gray was educated at Clare College, Cambridge, and University College Hospital. He qualified M.B., B.Chir. in 1942 and, after service in the Royal Navy, worked in the Department of Physiology at the National Institute for Medical Research. Thereafter he went with Sir Lindor Brown to the Department of Physiology in University College, London. $\mathrm{He}$ was awarded an Sc.D. (Camb.) in 1962 for his work on the mechanisms of sensory receptors, and the title of professor in physiology was conferred on him by the University of London in 1959. From 1957 until 1963 he was secretary of the Physiological Society, and since 1960 he has been dean of the Faculty of Science in the University of London.

Research Units

The Medical Research Council has set up a Demyelinating Diseases Research Unit in the University of Newcastle upon Tyne. The Unit will continue and expand investigations of the mechanisms of demyelination with special reference to the possible virological as well as allergic aspects of multiple sclerosis which were previously undertaken by the Research Group with the same title. The Unit remains under the honorary direction of Dr. E. J. Field, senior lecturer in neuropathology in the University of Newcastle upon Tyne, and Prof. H. G. Miller will continue as the Unit's honorary clinical adviser.

Dr. Wallace Fox has been appointed director of the Council's Tuberculosis and Chest Diseases Research Unit, following the retirement of Dr. P. D'Arcy Hart. The title of the Unit has been expanded to take account of its increasing work in the general field of chest diseases, including carcinoma of the bronchus.

Mr. John Bleby has been appointed director of the Council's Laboratory Animals Centre at the Medical Research Council Laboratories, Carshalton, following the resignation of Dr. W. Lane-Petter.

\section{Research Groups}

UNDER its scheme of Research Groups, the Research Council is able to provide additional support for the development of research programmes in university departments. The financial provision made available in this way enables the university to expand its staff and other resources devoted to the research in question, on the understanding that, after a stated period, it will assume responsibility for the further support of the work. The Council has agreed to provide the following university institutions with support for the establishment of research 